\title{
Transposition
}

Musique et Sciences Sociales

$8 \mid 2019$

Musique : patrimoine immatériel ?

\section{Laura Tunbridge, Singing in the Age of Anxiety: Lieder Performances in New York and London between the World Wars}

Chicago, University of Chicago Press, 2018

Jennifer Ronyak

\section{OpenEdition}

\section{Journals}

Electronic version

URL: http://journals.openedition.org/transposition/3696

DOI: $10.4000 /$ transposition.3696

ISSN: $2110-6134$

Publisher

CRAL - Centre de recherche sur les arts et le langage

\section{Electronic reference}

Jennifer Ronyak, "Laura Tunbridge, Singing in the Age of Anxiety: Lieder Performances in New York and London between the World Wars ", Transposition [Online], 8| 2019, Online since 15 September 2019, connection on 17 December 2020. URL : http://journals.openedition.org/transposition/3696 ; DOI : https://doi.org/10.4000/transposition.3696

This text was automatically generated on 17 December 2020.

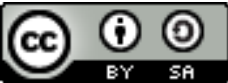

La revue Transposition est mise à disposition selon les termes de la Licence Creative Commons Attribution - Partage dans les Mêmes Conditions 4.0 International. 


\section{Laura Tunbridge, Singing in the Age of Anxiety: Lieder Performances in New York and London between the World Wars}

Chicago, University of Chicago Press, 2018

Jennifer Ronyak

\section{REFERENCES}

Laura Tunbridge, Singing in the Age of Anxiety: Lieder Performances in New York and London between the World Wars, Chicago, University of Chicago Press, 2018, 239 p.

In Singing in the Age of Anxiety: Lieder Performances in New York and London between the World Wars, Laura Tunbridge recalls a line from Paul Heyse that appears in Hugo Wolf's Italienisches Liederbuch: “Auch kleine Dinge können teuer sein" (Even little things can be precious) (p.11-12). Tunbridge takes this motto to heart in her masterful study, in which she considers the performance of Romantic German lieder in various contexts and in conjunction with new technologies in the two cities between the 1910s and 1940s. Yet Tunbridge stops short of treating lieder as so precious that they demand a detailed consideration of their music and poetry. Moving away from a reception history paradigm, in which works and their details are seen as "drivers of musical culture" (p. 2, citing Daniel Cavicchi), the author instead offers a "use history" (p. 2, citing historian of science David Edgerton): a study of how an older repertoire played an important role in society in general, even as newer musical developments were also underway. This is not to say that the musical characteristics of specific songs, performances, or recordings do not have some role to play in this book; in the cases when Tunbridge does discuss them, they are handled insightfully. But by focusing primarily on the role of the repertoire as a whole in diverse programming, critical, and 
technological contexts, the book allows us a valuable glimpse of a world in which lieder formed an ongoing if shifting musical currency for an elite musical class and those that would aspire to join them in their tastes. Tunbridge also offers a keen analysis of the ever-changing position of nationalism within the wartime and interwar cosmopolitan musical cultures of New York and London and the ways that changes in radio, audio recording, and film technologies played an important role in musical life. With this book, Tunbridge offers a valuable new approach to the contextual study of art song that should appeal not only to musicologists and historians, but to performing musicians and general readers interested in the genre and interwar culture.

2 The book proceeds roughly chronologically, with two outer chapters that focus, respectively, on the periods right at the end of the first world war and during the second, and with two inner chapters that focus on the interwar period. The themes of nationalism/cosmopolitanism, class, and technology that govern the study interweave productively in each chapter. Where the first of these topics is concerned, Tunbridge initially highlights it in the evocative vignettes which open chapter one. Looking at transatlantic travel by ship shortly after World War I, Tunbridge shows how chance meetings between musicians of various national identities could lead to impromptu cosmopolitan music making in this momentarily nationless space, even as concert contexts at either end of the journey would have forced musicians to contend with more nationalist priorities. For example, Elisabeth Schumann, a German soprano who was headed to tour America with Richard Strauss in 1921, encountered a number of international musicians on her transatlantic sea journey. The musical result was a charity concert on board in which she sang three Strauss songs to great success. Later in this chapter, we learn how singers like the German Schumann and the GermanAmerican contralto Ernestine Schumann-Heink had to negotiate their own Germanness, and the Germanness of the lied repertoire - especially as found in the original language of its poetry - in relationship to the hostility towards the German language that lingered in New York public recital contexts after the First World War. Things took a surprising turn where this issue was concerned in New York and London in the 1930s and during World War II, as Tunbridge points out in chapter four. In this later context, German was no longer simply the language of the enemy; instead, musicians and their audiences found it important to cultivate a cosmopolitan or universalist mindset by singing lieder in the original German, and by also supporting elite German musicians who were in exile in London and New York due to the Nazi control of Germany. Tunbridge returns to the question of the status of the Germanlanguage poetry in the lied repertoire in these two Anglophone cities elsewhere in the book as well. In chapter two, for example, there is an illuminating discussion on the status of singing lieder in translation in the interwar period and its relationship not just to nationalism or cosmopolitanism but to audience accessibility and music education initiatives.

3 The often unstable categories and, especially, changing social implications of highbrow, middlebrow, and popular taste with respect to lieder during the period are well-illuminated within chapters two and three. Well-positioned music critics and performers thought of lieder as a decidedly highbrow and refined art. But aspects of Romantic lieder left them well-poised to appeal to a less-refined middlebrow listener, a category that invoked listeners aspirationally open to elevating their tastes, so long as they could do so through relatively digestible bits of what was recognized as high 
culture. As Tunbridge notes on page 66, there came to be "a sense of a middlebrow repertoire, particularly in the realm of song, where aesthetics of moderation, synthesis, and sincerity came to the fore [...] Not all, but some, stretches of Schubert and Schumann could fulfill the middlebrow desire to combine the pleasures of the low with the prestige of the high. It is a kind of multivalence that can make categorization awkward and the musicologist's brow furrowed." Tunbridge luxuriates in this multivalence in her discussion of various music education projects for the general public involving lieder in print and, especially, on radio programs. The Schubert commemorations in 1928, for example, served as one focal point for such efforts. Otto Kahn of the Metropolitan Opera in New York devised a program by which "smaller communities that did not have access to live performances" (p. 58) would be provided with the technologies necessary to connect with the commemorative events, and the British music critic Richard Capell's Schubert's Songs appeared serialized in a monthly magazine, so that voice students and the wider public could build their appreciation of lieder. The most striking discussion of the implications of a middlebrow aesthetic for lieder comes in chapter three, however, in which Tunbridge discusses the presence of lieder in elite concert series in clubs, hotels, and similar venues in New York and London. In every way the organizers of and audiences for these events represented a pure cultural and economic elite in both cities. As Joan Rubin has pointed out, however, middlebrow taste or repertoires made up a "solid ground" for congealing the "genteel outlook" of such elite social groups (cited on p. 94). These elite social gatherings welcomed what could at least be perceived to be a conservative, digestible, sincere, and therefore middlebrow musical repertoire like nineteenth-century lieder. Indeed, it is hard to imagine that wealthy "ladies who lunch" would have met for a musical morning in the earlier twentieth century to hear a concert of staunchly avant-garde music.

4 Tunbridge describes throughout the book how the technologies of electric recording, radio, and sound film interacted with the various contexts and valuation systems that lieder encountered during the period. Very often, new recordings of lieder were driven by very specific concert events or promoters, and the recordings in turn provided a foundation for further musical community building and live events. Tunbridge's discussion of lieder in early sound film especially highlights how all of the main strands of argument in the book often congeal subtly in one place. In the section Atlantik/ Atlantic in chapter two, Tunbridge focuses on the presence of lieder in the multilanguage versions of sound films that were often produced not only in New York and London, but also in the German-speaking lands in the 1930s; such films were filmed in multiple, separate versions, using a new language each time for a new market. Through film, decidedly broad international audiences had the opportunity to see and hear singers of various levels of highbrow or popular status sing lieder onscreen, ranging from the tenor Jon McCormack (who played a classical singer in Song of My Heart), to the tenor Richard Tauber (who portrayed Schubert onscreen), to soprano Marta Eggerth (who portrayed multiple characters prone to singing lieder in several operetta-inspired films). While the repertoire presented was often made up of what are some of the still most valued and thus essentially highbrow songs in the lied canon, the various fictional scenarios of these films often played upon the middlebrow multivalence of lieder to make them sometimes seem just a hair's breath away from even popular or folk song.

5 This book may be primarily about the use and the shifting valence of a classic repertoire in a politically, socially, and technologically tempestuous time. But it is also a rather tender look at survival: not of the repertoire, but of the many professional 
musicians who faced enormous challenges while trying to simply preserve their art. One of the most moving historical accounts in this regard comes in the discussion of pianist Myra Hess's successful effort to mount a steady concert series at the National Gallery in London during the Second World War, when regular musical activity in the city had practically ceased. Tunbridge treats this scenario with what is perhaps the necessary dose of scholarly distance. But the effect of her account of this event, like that of many of the other richly multilayered scenarios in the book, is to remind the reader of the ongoing tenacity that has been central to practicing musicians' lives and continues to be so. Such tenacity must have felt especially important in the periods of wartime and the "age of anxiety" between them that Tunbridge brings to life so vividly.

\section{AUTHORS}

\section{JENNIFER RONYAK}

Jennifer Ronyak is Senior Scientist at the Institute for Musical Aesthetics of the University for Music and Performing Arts, Graz. She is the author of the book, Intimacy, Performance, and the Lied in the Early Nineteenth Century (Indiana University Press, 2018), and has published further research on German art song in the Journal of the American Musicological Society, Nineteenth-Century Music, the Journal of Musicology, and Music \& Letters. 